\title{
The Relationship between Hope and Perceived
}

\section{Stress in Teacher Candidates}

\author{
Serdar Sucan ${ }^{1}$ \\ ${ }^{1}$ Faculty of Sport Sciences, Erciyes University, 38039 Kayseri, Turkey \\ Correspondence: Serdar Sucan, Faculty of Sport Sciences, Erciyes University, 38039 Kayseri, Turkey. E-mail: \\ sesucan@hotmail.com
}

Received: February 5, 2019

Accepted: March 18, 2019

Online Published: March 19, 2019

doi:10.5430/ijhe.v8n2p1

URL: https://doi.org/10.5430/ijhe.v8n2p1

\begin{abstract}
The long-term and uncontrollable stress of KPSS (Personnel Selection Examination) candidates disrupts their psychology, weakens thinking and decision-making, and thus decreases academic achievement. The aim of this study is; It is the determination of the relationship between the level of hope and perceived stress of teacher candidates prepared for KPSS.

A total of 382 teacher candidates participated in a special KPSS preparatory course in Kayseri. Candidate teachers who graduated from different departments and universities are between the ages of $21-25$ in $41.6 \%$. When we look at socio-demographic characteristics; $68.4 \%$ male; $59.9 \%$ single and $51.5 \%$ were at medium income level. Perceived Stress Scale (PSS-10) and Adult Hope Scale (AHS) were administered to the participants. The mean AHS score of the teacher candidates was $27.73 \pm 1.92$. This shows the high level of hope of the participants. Perceived Stress level was found to be medium at 53.6\%. As a result of the analysis, a significant a negative correlation was found between level of hope and perceived stress ( $p<0.01$ ). According to regression analysis, level of hope in teacher candidates showed a statistically significant positive effect on perceived stress $(\mathrm{p}<0.01)$.

As a result, negative relationships were found between hope and perceived stress. It is thought that highly hopeful people perceive stress lower and life satisfaction increases. Therefore, in order to increase the level of hope and to reduce the negative effects of stress, educators should support KPSS candidates. Programs related to the high level of hope to be implemented in schools may have positive effects on individuals' low stress and examinations.
\end{abstract}

Keywords: hope, perceived stress, teacher, candidates

\section{Introduction}

Universities are the reflection of society with their truths and mistakes. In universities, new and basic information is produced and professional skills are gained. Universities are the pioneers in the development of ideas and alternative skills (Rosovsky, 1998). At the university, students experiencing problems experience physical or psychological pressure. Universities are very important institutions in terms of professional life. Faculties aim to provide appropriate attitudes and behaviors to students as well as professional knowledge. It is stated that there is a relationship between academic processes and stress. (Agolla and Ongori, 2009).

Students experiencing high levels of stress experience problems such as family retreat, foreign environment, housing conditions, adolescence problems, economic difficulties, new friends and regular nourishment. (Pamuk et al., 2014). In addition, problems such as passing lessons, assignments, lack of time, lack of planning, and concerns about finding a job are important sources of stress for students. (Savc1 and Aysan, 2014). It has been said that stress has a detrimental effect on health and negatively affects performance. (Ünal and Ümmet, 2005). Stress, along with health, which has a comprehensive and negative impact on daily life (Kinman, 1998), arises from the forcing or threatening of the physical and psychological capacity of the organism. (Baltaş and Baltaş, 2000).

In the education system in our country, exams are very important. Students who begin their education life experience high levels of stress due to family and teacher pressure. Studies have shown that the expectation about education creates stress on students. (Akçamete, 2002). Examinations, which are a source of significant stress, are the stimulants that cause anxiety and stress, which are related to the status of the individual and provide important 
decisions (Zeidner, 2004). The KPSS (Personnel Selection Examination), which is a career determinant, is an important obstacle for many people. People who perceive the exam and especially the exam result as a major obstacle to their career experience a high level of anxiety and stress (Peleg-Popko, 2004).

People who think positively about themselves exhibit attitudes that will improve their thinking (Pierce and Gardner, 2004). However, KPSS candidates may experience high levels of stress due to these negative situations. Future anxiety and fear of separation from the family, depressive mood may occur (Wohl, DeShea and Wahkinney, 2008). Because of these situational factors, the problem is that the candidates who are living, the hope decreases, and the more they perceive stress.

Human behavior is directed towards a purpose and determines the direction of mental activity. The methods of achieving the purpose are the perception of being able to produce appropriate methods for achieving the purpose of the person (Snyder, Rand \& Sigmon, 2002). The hope is to make a positive and motivating plan for the purpose and to go for the purpose (Peterson et al., 2011). Hope is a positive condition for the relationship between motivation and reaching the goal. Those who have high levels of hope can try many methods to achieve their goal (Snyder, 2000).

In childhood, struggling with objective barriers improves hopeful thinking. People overcome problems with this hope. The mechanism of hope is constantly working and this is the situational stamina of hope (Snyder et al., 1997). The low level of hope disrupts the psychology of the person and, together with these negative emotions, may negatively affect the KPSS, which is a major obstacle to his career. As a matter of fact, in different studies, the positive motivation, interest, effort and positive emotions of the students in their academic lives are positive; a negative relationship was found between stress and hope (Pekrun et al., 2002; Vilaythong et al., 2003; Snyder et al., 2000; Snyder et al., 2002).

KPSS candidates, long-term and uncontrollable stress, disrupting their psychology, thinking and decision-making by weakening, academic success is considered to reduce. Fighting with stress is important for candidates to develop appropriate behaviors, to be successful and to gain a profession. In order to increase the level of hope, educators should support the candidates preparing for the KPSS and the negative effects of stress should be reduced. The aim of this study; It is the determination of the relationship between the level of hope and perceived stress of teacher candidates prepared for KPSS.

\section{Method}

\subsection{Participants}

In this study, 382 volunteer teacher candidates from different departments and universities participated in a special KPSS preparation course in Kayseri. When we look at the teacher candidates demographic information; 68.4\% male; $59.9 \%$ single; $41.6 \%$ between the ages of $21-25 ; 51.5 \%$ were middle income level. Shows the demographic information of the teacher candidates participating in the study (Table 1).

Table 1. Demographic Information of Teacher Candidates $(\mathrm{n}=382)$

\begin{tabular}{llcc}
\hline \multicolumn{1}{c}{ Variables } & \multicolumn{1}{c}{ Categories } & f & \% \\
\hline \multirow{2}{*}{ Gender } & Female & 121 & 31.6 \\
& Male & 261 & 68.4 \\
\hline \multirow{3}{*}{ Age (years) } & $21-25$ years & 159 & 41.6 \\
& $26-30$ years & 108 & 28.3 \\
& 31-35 years & 74 & 19.4 \\
& 36 years and over & 41 & 10.7 \\
\hline \multirow{2}{*}{ Marital status } & Single & 229 & 59.9 \\
& Married & 153 & 40.1 \\
\hline \multirow{3}{*}{ Revenue } & Low & 118 & 30.8 \\
& Medium & 197 & 51.5 \\
& High & 67 & 17.7 \\
\hline
\end{tabular}




\subsection{Instruments}

\subsubsection{Perceived Stress Scale (PSS-10)}

The Perceived Stress Scale (PSS)-10 item version was developed by Cohen et al. (1983) to measure the individual's appraisals of stressful life events (Cohen et al., 1983). Its validity and reliability studies were performed by Erci (2006) and Bilge et al. (2009) and were then adapted to Turkish society. Items were designed to reveal the degree to which respondents found their lives unpredictable, uncontrollable, and overwhelming in the last one month. The PSS-10 is a five point Likert scale ranging from $(0=$ never to $4=$ very often). There are four reverse items which are written positively (items 4,5,7 and 8). Total scores range from 0 to 40 with higher scores indicating higher perceived stress. The internal consistencies of the original scale change from 0.75 to 0.86 . In the present study PSS-10 had internal consistency (Cronbach's alpha) of $\alpha=0.71$.

\subsubsection{Adult Hope Scale (AHS)}

The Adult Hope Scale developed by Snyder et al. (1991) includes 12 questions for individuals aged 15 years and over. Likert type four digits ( $1=$ otally wrong and totally true $=4$ ). So, the scores range will be between 8 and 32.4 questions are about the bus in operation, 4 questions are diversion and other questions are not scored. Total scores of subscale of the bus will constitute the overall score of hope. The higher the scores, the greater the hopes. The Cronbach alpha reliability coefficient of the scale was calculated to be 0.73 . In the present study AHS had internal consistency (Cronbach's alpha) of $\alpha=0.75$.

\subsection{Data Analysis}

The data obtained in the research were presented as frequency (f), percentage (\%), arithmetic mean $(\overline{\mathrm{X}})$ and standard deviation (SS). t-test, ANOVA test, Tukey test, Spearson Correlation Coefficient, Simple and Multiple Regression Analysis were used for the relationship between variables. The SPSS package software was utilized for analyses of collected data; and significance was determined as $\mathrm{p}<0.05$.

\section{Results}

The mean "Adult Hope Scale" score of the teacher candidates was 27.73 \pm 1.92 . This finding shows the high level of hope of the candidates.

Table 2. Perceived Stress Level of Teacher Candidates

\begin{tabular}{lccc}
\hline & Perceived Stress & N & \% \\
\hline High & 129 & 33.7 \\
Medium & 205 & 53.6 \\
Low & 48 & 12.7
\end{tabular}

In addition, the stress levels of teacher candidates were 33.7\% high, 53.6\% medium and $12.7 \%$ low (Table 2).

Table 3. Test Results of Perceived Stress Scale Scores by Gender Variable

\begin{tabular}{lcccccccc}
\hline & Group & $\mathrm{N}$ & $\overline{\mathrm{X}}$ & $\mathrm{SS}$ & \multicolumn{3}{c}{$\mathrm{t}$ Test } \\
\cline { 6 - 8 } & & & & & $\mathrm{t}$ & $\mathrm{Sd}$ & $\mathrm{p}$ \\
\hline \multirow{2}{*}{ Perceived Stress } & Male & 312 & 21.348 & 5.372 & & \multirow{2}{*}{0.269} & 435 & 0.001 \\
& Female & 173 & 24.281 & 5.905 & & & &
\end{tabular}

The perceived stress scores of teacher candidates showed a significant difference according to gender variable $(p<0.05)$. Accordingly, the mean stress score of female was higher than that of male (Table 3 ).

Table 4. Regression Test Results Regarding The Relation Between "Hope Level" and "Perceived Stress" Variables

\begin{tabular}{ccccccccc}
\hline & \multicolumn{2}{l}{ Variables } & \multicolumn{2}{c}{ Model Summary } & \multicolumn{2}{c}{ Anova } & \multicolumn{3}{c}{ Coefficients } \\
\hline \multirow{2}{*}{ Constant } & Dependent & $\mathrm{R}^{2}$ & $\mathrm{R}$ & $\mathrm{F}$ & $\mathrm{p}$ & $\beta$ & $\mathrm{t}$ & $\mathrm{p}$ \\
\hline \multirow{2}{*}{ Hope } & \multirow{2}{*}{ Perceived Stress } & \multirow{2}{*}{0.105} & \multirow{2}{*}{0.324} & \multirow{2}{*}{14.114} & 0.001 & 5.549 & 9.436 & 0.001 \\
& & & & & & -0.324 & -3.757 & 0.001 \\
\hline
\end{tabular}

$\mathrm{Y}($ Perceived Stress) $=5.459-0.413$ (Hope) 
According to regression analysis, the teacher candidates level of hope is a significant predictor of perceived stress $(\mathrm{F}=14.114)$. According to this, there is a high, negative and significant relationship between hope scores and perceived stress scores $(\mathrm{p}<0.01)$ (Table 4).

Table 5. Correlation Test Results Regarding The Relation Between "Hope Level" and "Perceived Stress" Variables

\begin{tabular}{lllll}
\hline Variables & $\overline{\mathbf{X}}$ & SS & $\mathbf{1}$ & $\mathbf{2}$ \\
\hline 1. Perceived Stress & 22.81 & 0.84 & 1 & \\
2. Hope Level & 27.73 & 1.92 & $0.001^{* *}$ & 1 \\
\hline
\end{tabular}

$\mathrm{p}<0.05^{*}, \mathrm{p}<0.01^{* *}$

As a result of the correlation analysis, there was a high, negative and significant relationship between perceived stress scores with the level of hope scores of teacher candidates ( $p<0.01)$ (Table 5).

\section{Discussion and Conclusion}

Teaching is a profession that requires expertise and skills. Teaching is seen as a profession because it is a profession related to human beings. KPSS exam is very important in terms of teacher candidates career (Karataş and Güleş, 2013). Candidates who work for the exam and see the exam as a turning point, experience high stress in this period (Ceyhan, 2005; Doğan and Çoban, 2009). The aim of this examination, which aims to select the most knowledgeable among the teacher candidates, is to be more successful than the other candidates. In order to achieve this goal, teacher candidates who think that they need to work more and more are under intense stress and pressure. Many factors influence the mood of the teacher candidates, the preparation process, and ultimately the exam success.

Hope is an important way of thinking that guides human life. When we think that this thought is formed from childhood, the studies with children are considered important. Therefore, the development and acquisition of hopeful ideas will make children more ready for life. Factors such as negative thinking, social pressure and future anxiety about KPSS will increase the perceived stress level of candidate teachers. This negative thought created by high level of stress, together with the support of the family, will contribute to the hopefulness of the person. As a matter of fact, it is said that social support positively affects the psychological well-being of adolescents, and foresees hopeful thinking by improving their coping skills (Won, 2011).

When we look at the findings of the study that examined the effect of hope on perceived stress, a negative correlation was observed between the level of hope and perceived stress. This finding shows that while the level of hope of the candidates increases, the perceived stress decreases. Accordingly, we can say that people with high levels of hope experience less stress in daily life or do not feel intensely stressed. In our country, there are studies about the level of hope of students (Akman and Korkut, 1993; Denizli, 2004; Kemer, 2006; Kemer and Atik, 2005).

According to McGregor and Little (1998), achievable goals are associated with prosperity. In a study conducted in students, it was said that the low level of hope increased the education stress. (Özdemir and Özdemir, 2015). In a similar study, it was found that there was a negative relationship between self-esteem, hope and social support and stress (Lee and Hwang, 2016).

Similarly, with the stress-reducing effect of hope, it has been found that it has a positive effect on performance and job satisfaction (Youssef and Luthans, 2007). In another study, it was concluded that the perception of positive psychological capital as a support positively affects the performance of the candidates who will take the exam (Luthans, 2002). Hasnain, Wazid and Hasan (2014) emphasizes the importance of thinking with hope on preventing problems and increasing strength and emphasized that hope would have important contributions in both before and afterthe emergence of problems. The results of the literature support our findings.

\section{Conclusion}

KPSS is a difficult test that selects the most knowledgeable teacher candidates. Teachers who think that it is very difficult to win and that they need to study more, experience intense stress and pressure during this period. The only way for candidates to be successful in the exam and to be appointed is to learn the techniques of coping with stress and to be highly hopeful. As a matter of fact, it is said that those with high levels of hope experience less stress and higher quality of life. (Fitness 2001; Runcan and Iovu, 2013).

Therefore, stress factors that candidates perceive as a threat to their learning environment and social environment should be regulated according to anti-stress principles. In addition, it may be necessary for the family and teachers to 
learn about the socially supported behavioral models they will show against the candidates.

On the macro level, we propose that the teaching profession be revised in order to gain the prestige of the society and the teaching programs should be arranged in a way that will ensure the supply-demand balance.

\section{References}

Agolla, J. E., Ongori, H. (2009). An assessment of academic stress among undergraduate students: The case of university of Botswana. Educational Research and Review, 4(2), 63-70.

Akçamete, G. (2002). Öğretmenlerde Tükenmişlik, İş Doyumu ve Kişilik. Nobel Yayın Dağıtım, Ankara.

Akman,Y., Korkut, F. (1993). Umut Ölçeği Üzerine Bir Çalışma. H.Ü. Eğitim Fakültesi Dergisi, 9, 193-202.

Baltaş, A., Baltaş, Z. (2000). Stres ve Başaçıkma Yolları, 20. Baskı, Remzi Kitapevi, İstanbul, 26.

Bilge, A., Öğce, F., Genç, R.E., Oran, N.T. (2009). Psychometric Compatibility of The Turkish Version of The Perceived Stress Scale. Journal of Ege University School of Nursing, 25(2), 61-72.

Ceyhan, A. A. (2005). Öğretmen Adaylarının Umutsuzluk Düzeylerinin İncelenmesi. Eğitim ve Bilim, 30(167), 63-73.

Cohen, S., Kamarck, T., Mermelstein, R. (1983). A Global Measure of Perceived Stress. Journal of Health and Social Behavior, 24(4), 385-396. https://doi.org/10.2307/2136404

Denizli, S. (2004). The Role of Hope and Study Skills in Predicting Test-Anxiety Levels of University Students (Unpublished Master's Thesis). Middle East Technical University, Ankara.

Doğan, T., Çoban, A. E. (2009). Eğitim Fakültesi Öğrencilerinin Öğretmenlik Mesleğine Yönelik Tutumları İle Kayg1 Düzeyleri Arasındaki İlişkinin İncelenmesi. Eğitim ve Bilim, 34, 157-168.

Erci, B. (2006). Reliability and valididy of the Turkish version of perceived stress scale. Journal of Anatolia Nursing and Health Sciences, 9(1), 58-63.

Fitnes, J. (2001). Emotional intelligence and intimate relationship. In J. Ciarrochi, J. P. Forgas, J. D. Mayer (Ed.), Emotional intelligence in everyday life. Philadelphia: Psychology Pres. 98-112.

Hasnain, N., Wazid, S. W., Hasan, Z. (2014). Optimism, Hope, and Happiness as Correlates of Psychological Well-Being Among Young Adult Assamese Males and Females. IOSR Journal Of Humanities And Social Science (IOSR-JHSS), 19(2), 44-51. https://doi.org/10.9790/0837-19224452

Karataş, S., Güleş, H. (2013). Öğretmen Atamalarında Esas Alınan Merkezi Sınavın (KPSS) Öğretmen Adaylarının Görüşlerine Göre Değerlendirilmesi. Kuramsal Eğitim Bilim Dergisi, 6(1), 102-119.

Kemer, G. (2006). The role of self-efficacy, hope, and anxiety in predicting university entrance exam scores of eleventh-year students. Unpublished master's thesis, Middle East Technical University, Ankara.

Kemer, G., Atik, K. (2005). Comparison of Secondary School Students Living in Urban and Rural According to Level of Social Support Taken from Family. M.U. Atatürk Eğitim Faculty of Education Educational Sciences Journal, 21, 162-168.

Kinman, G. (1998). Pressure Points - A Survey into the Causes and Consequences of Occupational Stress in UK Academic and Related Staff, http: //www.uofaweb.ualberta.ca/aasua//pdfs/pressurepoints.pdf (Erişim:10.02.2019).

Lee, C. S., Hwang, Y. K. (2016). The Effects of Hope, Emotional Intelligence, and Stress on the Self-esteem of Rural Elementary School Students in Korea: The Mediating Effect of Social Support. Indian Journal of Science and Technology, 9(26), 1-7. https://doi.org/10.17485/ijst/2016/v9i26/97278

Luthans, F. (2002). Positive Organizational Behavior: Developing and Managing Psychological Strengths. Academy of Management Executive, 16, 57-72.

McGregor, I., Little, B. R. (1998). Personal Projects, Happiness, and Meaning: on Doing Well and Being Yourself. J. of Personality \& Social Psy., 74(2), 494-512. https://doi.org/10.1037/0022-3514.74.2.494

Özdemir, Y., Özdemir, M. (2015). Eğitim Stresi ve Benlik Saygısının Ortaokul Öğrencilerinin Okul Tükenmişliği Üzerindeki Doğrudan ve Dolaylı Etkileri. Adnan Menderes Üniversitesi Eğitim Fakültesi Eğitim Bilimleri Dergisi, 6(2), 1-10. http://dergi.adu.edu.tr/egitimbilimleri/

Pamuk, Y., Hamurcu, H., Armağan, B. (2014). Sınıf Öğretmeni Adaylarının Durumluk ve Sürekli Kaygı 
Düzeylerinin İncelenmesi (İzmir-Buca Örneği), Bartın Üniversitesi Eğitim Fakültesi Dergisi, 3(2), 293-316. https://doi.org/10.14686/BUEFAD.201428183

Pekrun, R., Goetz, T., Titz, W., Perry, R. P. (2002). Academic Emotions in Students Self-Regulated Learning and Achievement: A Program of Quantitative and Qualitative Research. Educational Psychologist, 37, 91-105. https://doi.org/10.1207/S15326985EP3702_4

Peleg-Popko, O. (2004). Differentiation and Test Anxiety in Adolescents, Journal of Adolescence, 27, 645-662. https://doi.org/10.1016/j.adolescence.2004.06.002

Peterson, S. J., Luthans, F.; Avolio, B. J., Walumbwa, F., Zhang, Z. (2011). Psychological Capital and Employee Performance: A Latent Growth Modeling Approach. Personnel Psychology, 64, 427-450. https://doi.org/10.1111/j.1744-6570.2011.01215.x

Pierce, J. L., Gardner, D.G. (2004). Self-Esteem Within the Work and Organizational Context: A Review of the Organization-Based Self-Esteem Literature. Journal of Management, 30(5), 591-622. https://doi.org/10.1016/j.jm.2003.10.001

Rosovsky, H. (1998). Üniversite (Bir Dekan Anlatıyor). Çeviren. S. Ersoy. Tübitak Yayınları, Ankara.

Runcan, P. L., Iovu, M. B. (2013). Emotional Intelligence and Life Satisfaction in Romanian University Students: The Mediating Role of Self-Esteem and Social Support. Revista De Cercetare Si Interventie Sociala, 40, 137-148.

Savc1, M., Aysan, F. (2014). Üniversite Öğrencilerinde Algılanan Stres Düzeyi İle Stresle Başa Çıkma Stratejileri Arasındaki İlişki. Uluslararası Türk Eğitim Bilimleri Dergisi, Ekim, 44-56.

Snyder, C. R. (2000). The Past and Future of Hope. Journal of Social and Clinical Psychology, 19, 11-28. https://doi.org/10.1521/jscp.2000.19.1.11

Snyder, C. R., Feldman, D. B., Taylor, J. D., Schroeder, L. L., Adams, V. (2000). The Roles of Hopeful Thinking in Preventing Problems and Enhancing Strengths. Applied and Preventive Psychology, 15, 262-295. https://doi.org/10.1016/S0962-1849(00)80003-7

Snyder, C. R., Harris, C., Anderson, J. R., Holleran, S. A., Irving, L. M., Sigmon, S. T. (1991). The Will and The Ways: Development and Validation of an Individual-Differences Measure of Hope. Journal of Personality and Social Psychology, 60, 570-585. https://doi.org/10.1037/0022-3514.60.4.570

Snyder, C. R., Hoza, B., Pelham, W. E., Rapoff, M., Ware, L., Danovsky, M.. (1997). The development and validation of the Children's Hope Scale. Journal of Pediatric Psychology, 22(3), 399-421. https://doi.org/10.1093/jpepsy/22.3.399

Snyder, C. R., Rand, K. L., Sigmon, D. R. (2002). Hope Theory: A Member of The Positive Psychology Family. In Snyder, C. R., Lopez, S. J. (Eds.), Handbook of Positive Psychology, NY: Oxford University Press, 257-276.

Snyder, C. R., Shorey, H. S., Cheavens, J., Pulvers, K. M., Adams III, V. H., Wiklund, C. (2002). Hope and academic success in college. Journal of Educational Psychology, 94, 820-826. https://doi.org/10.1037/0022-0663.94.4.820

Ünal, S., Ümmet, D. (2005). Örgütsel Stres Kaynakları Ve Öğretmenlerin Baş Etme Stratejileri, Pamukkale Üniversitesi Yayınlar, Denizli.

Vilaythong, A. P., Arnau, R. C., Rosen, D. H., Mascaro, N. (2003). Humor and Hope: Can Humor Increase Hope? Humor, 16(1), 79-89. https://doi.org/10.1515/humr.2003.006

Youssef, C., Luthans, F. (2007). Positive Organizational Behavior in the Workplace: The Impact of Hope, Optimism and Resilience. Journal of Management, 33(5), 774-800. https://doi.org/10.1177/0149206307305562

Wohl, M., DeShea, L., Wahkinney, R. L. (2008). Looking Within: Measuring State Self-Forgiveness and Its Relationship to Psychological Well-Being. Canadian Journal of Behavioural Science, 40(1), 1-10. https://doi.org/10.1037/0008-400x.40.1.1.1

Won, D. R. (2011). The Effects of Social Support, Hope and Coping with Problem Solving on The Psychological Wellbeing: The Mediating Roles of Hope and Coping with Problem Solving. Korean Journal of Health Psychology, 16(2), 297-311. https://doi.org/10.17315/kjhp.2011.16.2.004

Zeidner, M. (2004). Test Anxiety, Encyclopedia of Applied Psychology, 545-556. 